\title{
ENVIRONMENTAL DIMENSIONS OF RURAL DEVELOPMENT IN LAND USE PLANNING CIRCUMSTANCES IN UKRAINE
}

\author{
Nataliia Stoiko ${ }^{1}$, Velta Parsova ${ }^{2}$ \\ ${ }^{1}$ Lviv National Agrarian University, Ukraine; ${ }^{2}$ Latvia University of Agriculture \\ n_stoiko@ukr.net, velta@parsova.lv
}

\begin{abstract}
One of the tools for management of balanced development of rural areas is spatial planning - a kind of activity regarding to organization of use and protection of land at the national, regional and local level. The issues of conservation and restoration of natural resources in rural areas are extremely relevant for Ukraine. Main environmental problems in rural areas are - degradation of agricultural land, loss of biodiversity and pollution of land, overground and underground water. In recent years a new environmental problem has emerged desertification. The aim of the article is to investigate the possibilities of land use planning at regional and local level in order to improve the ecological situation in rural areas of Ukraine. To achieve the goal, scientific approaches and methods are used - system approach, system-analytical method, method of correlationregression analysis, abstract-logical method, etc. Investigating the existing system of territorial planning of Ukraine, there is determined discrepancy between the tasks of urban planning and land management in the sphere of solving environmental issues of land use. Also a negative trend in land conservation measures is noticed there, while the land degradation in the form of soil erosion is significant and widely distributed in the country. To solve the environmental problems of land use, it is proposed to introduce landscape planning as an important part of integrated management of land use in rural areas. There are described the stages of implementation of landscape planning. It is proposed to develop a landscape program and a framework landscape plan at the regional level, and a landscape plan at the local level. In general, landscape planning should be interlinked with spatial planning as a basis for solving issues of conservation and restoration of natural landscapes, formation of cultural landscapes and management of landscapes.
\end{abstract}

Keywords: land use, rural development, spatial planning, land degradation, landscape planning, environmental sustainability of the territory.

\section{Introduction}

In many countries spatial planning is an important constituent of territory development management. In the European Regional/ Spatial Planning Charter, spatial planning includes geographical depiction of economic, social, cultural and ecological policy of society. It describes complex managerial solutions concerning spatial organisation of territories according to the general strategy of regional development. The aim of the planning is to arrange and regulate efficient use of land for social needs [1]. Acceleration of ecological problems forces actuality of environmental planning expecting solutions concerning land use with consideration of natural conditions, social, economic and political factors to supply sustainable development of the territories [2].

In Ukraine, agricultural land occupies $71 \%$ of the total area and the issue of sustainable development of rural territories is of urgent importance. Protection of natural resources in rural location, in particular development of its natural-reserve fund with attraction of territorial communities of villages, settlements and business entities, is among the principal directions of implementation of the Concept of Rural Territory Development.

According to the Environmental Performance Index, which estimates the level of ecosystem sustainability (natural resource management) and environmental health (impact of the environment on human health), Ukraine took the $44^{\text {th }}$ position (79.69) among other countries of the world in 2016. This index has increased for the last 10 years but it is still the lowest among the neighbouring countries, i.e. the Slovak Republic (85.42), Hungary (84.6), the Russian Federation (83.52), Romania (83.24), Belarus (82.3) and Poland (81.26) [3]. Thus, it is necessary to carry out research concerning ecological aspects of land use planning in the rural territory of Ukraine as an important constituent of spatial planning.

The aim of the article is to study opportunities of land management planning at the regional and local levels for improvement of the ecological situation in rural territories of Ukraine. To reach the aim, the following tasks were set out - to characterize the peculiarities of land management planning in Ukraine, to analyse the tendencies of land resource protection and reclamation in rural area and to determine opportunities of spatial planning to make land management in rural area more ecological. 


\section{Materials and methods}

The research was carried out with consideration of sustainable development and the tasks, declared in the regulatory documents of Ukraine, the national ecological policy and development of rural territories. Information base of the research includes scientific works on the research topic; data of the Main Office of the State Service of Ukraine on the issues of geodesy, cartography and cadaster and the State Statistics Service of Ukraine; the Internet information resources.

On the territory of Ukraine, there are 28388 rural settlements and 885 urban-type settlements. Rural population constitutes $31 \% .71 \%$ of land stock is used for agricultural needs, including $54 \%$ as arable land, $4 \%$ as hay fields, $9 \%$ as pastures. Forests cover $17 \%$ of the territory. Nature reserves constitute $6 \%$ [4].

In Ukraine, the main ecological problems of land management in rural territories include degradation of agricultural land, loss of biological diversity, land and water pollution. Water and wind soil erosions (approximately $57 \%$ of the country territory) are the most widely spread kinds of soil erosion. The area of arable land with eroded soil increases by 60-80 thousand ha every year, approximately 4.5 million ha of arable land are with medium- and heavy-eroded soils, 68 thousand ha have completely lost their humus horizon. The area of active ravines constitutes 157 thousand ha, and their negative impact is revealed in the adjacent area of 1 million ha [5].

The research applies the system approach, when all processes of land management planning are analysed in dependences, the system-analytical method, used for study of legislative acts and other regulatory documents, the method of correlation-regressive analysis, used for determination of functional dependence between the factors of anthropogenic impact on soil erosion, as well as the abstract-logical method, used for theoretical generalization and formulation of conclusions.

\section{Results and discussion}

In Ukraine, land use planning is established at the national, regional and local levels. The principal strategic steps are described in the National program of land use and land protection. The aim of the program includes:

- distribution of land resources to satisfy needs of population and economic branches and supply food safety;

- protection of land resources from exhaustion, degradation and pollution;

- protection of landscape and biological variety, supply of ecologically safe conditions for life and economic activity of population [6].

The National program of land use and protection is an element of the General Scheme of territory planning in Ukraine. A regional program of land use and protection is an element of the Scheme of territory planning of regions or districts.

Ecological element of spatial planning is presented in:

- General Scheme of territory planning in form of proposals concerning environmental protection, with consideration of establishment of the National ecological network;

- Scheme of territory planning in a region or district, developing measures of environmental protection and rational use of natural resources [7].

The issues of use and protection of land resources at the regional level are included in the scheme of land organisation and technical-economic argumentation of land use and protection in administrative-territorial units [8] (Fig. 1).

Legislative acts of Ukraine define relations between the tasks of city-planning and land-surveying documentation in the field of land use at the regional level. Thus, the authors believe that:

- the Scheme of territory planning in a region or district is the base for development of a program of economic and social development;

- the Scheme of land organisation and technical-economic argumentation of land use and protection in administrative-territorial units is the base for development of a program of land use and protection. 
The Scheme of land organisation includes principal planning measures concerning land protection, based on a detailed study of natural-resource potential of the particular territory. The Scheme of land organisation is the base for development of the project documents of land organisation concerning the territory organisation, land reclamation and conservation, etc.

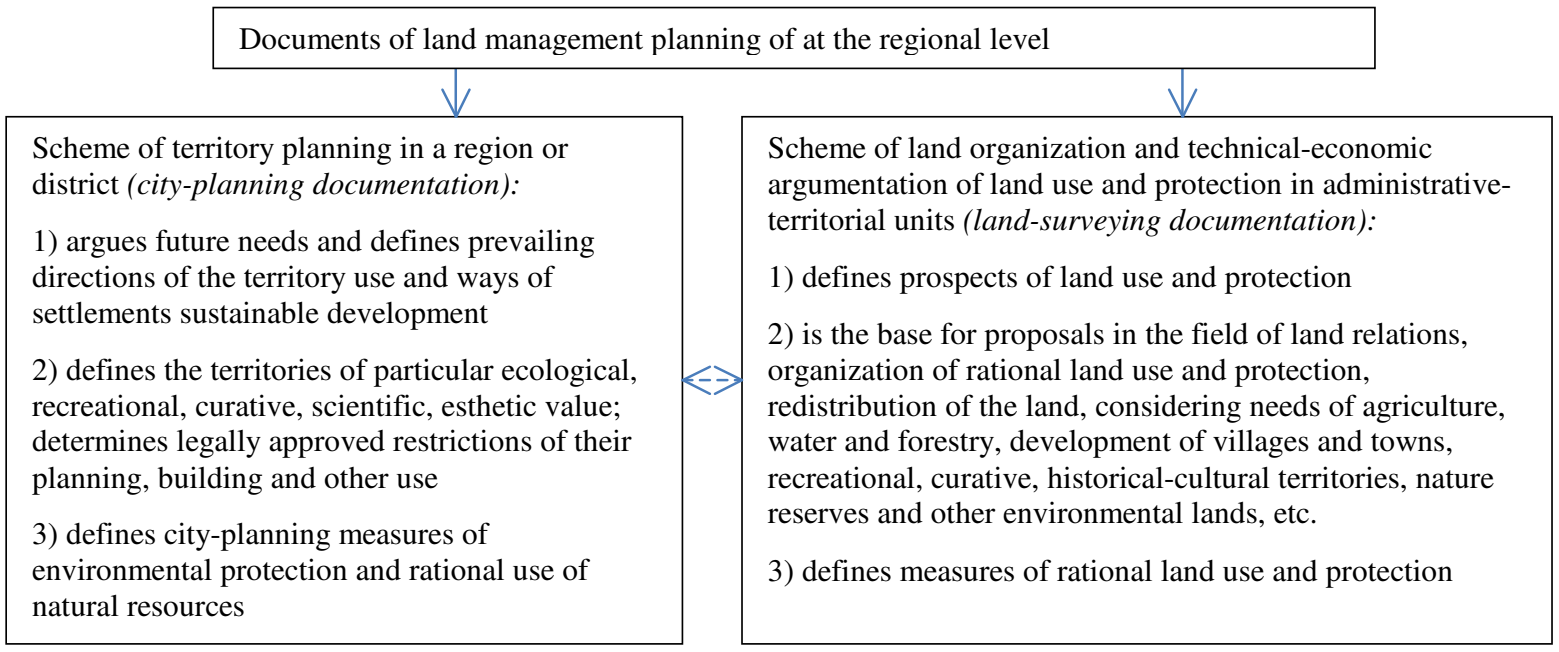

Fig. 1. Tasks of land use planning at the regional level in Ukraine

Ukraine has the legal background for implementation of ecological policy in the field of spatial planning of land management. Nevertheless, recently a negative tendency has been observed concerning implementation of land protection measures (Table 1) [4; 9].

Dynamics of introduction of land protection measures in Ukraine

Table 1

\begin{tabular}{|l|c|c|c|c|c|}
\hline \multirow{2}{*}{\multicolumn{1}{|c|}{ Land protection measure }} & \multicolumn{5}{|c|}{ Year } \\
\cline { 2 - 6 } & $\mathbf{1 9 9 5}$ & $\mathbf{2 0 0 0}$ & $\mathbf{2 0 0 5}$ & $\mathbf{2 0 1 0}$ & $\mathbf{2 0 1 5}$ \\
\hline Land conservation, thousand, ha & 12.8 & 15.0 & 6.3 & 1.0 & 0.2 \\
\hline Land reclamation, thousand, ha & 8.4 & 3.7 & 2.1 & 0.5 & 0.1 \\
\hline $\begin{array}{l}\text { Building of anti-erosion hydro-technical } \\
\text { constructions, km: }\end{array}$ & & & & & \\
\hline$\quad$ ramparts, ditch-ramparts, km & 135.2 & 9.3 & 3.6 & 4.1 & - \\
\hline terrace-ramparts, km & 5.4 & 10.9 & 6.6 & - & - \\
\hline coastal fortifications, km & 1.0 & 4.7 & 3.9 & 4.3 & - \\
\hline $\begin{array}{l}\text { anti-erosion stands (accumulators of } \\
\text { solid discharge), ha }\end{array}$ & 177.0 & 24.0 & 7.0 & 6.6 & - \\
\hline
\end{tabular}

Use of agricultural land on the slopes of more than $3^{\circ}$ is one of the factors of soil erosion development. A study of the interconnection between extension of area of eroded soils and area of arable land on $3-5^{\circ}$ slopes was carried out in 25 administrative territorial units of Ukraine (24 regions and the Autonomous Republic of Crimea) (Table 2).

The results of the analysis affirm the average degree of relations $(R=0.57)$ between the share of eroded arable land and the share of arable land on $3-5^{\circ}$ slopes in the structure of arable land, and the strong relation $(R=0.7)$ between the share of eroded agricultural land and the share of agricultural land on $3-5^{\circ}$ slopes in the structure of agricultural land. There is a direct dependence between the resultative and factorial characteristics, i.e. increase of the share of arable land on $3-5^{\circ}$ slopes causes increase of the share of eroded arable land.

Improvement of ecological situation in land management on rural territories needs a complex (integrated) approach to management of land resources, which is focused on ecologisation of land use and development of environmental activity in rural location. The main task of the integrated management of land use is to support the necessary quantity and quality of land resources for the present and future generations [10]. 
Table 2

Value of the coefficients of regression of agricultural development and land development impact on the share of eroded soils in Ukraine (2016)

\begin{tabular}{|l|l|l|l|}
\hline Indicator & Regression equation & $\begin{array}{l}\text { Correlation } \\
\text { coefficient }\end{array}$ & $\begin{array}{l}\text { Determination } \\
\text { coefficient }\end{array}$ \\
\hline Share of agricultural land on $3-5^{\circ}$ slopes & $y=2.3647 x+10.16$ & 0.70 & 0.49 \\
\hline Share of arable land on $3-5^{\circ}$ slopes & $y=1.7824 x+14.952$ & 0.57 & 0.32 \\
\hline
\end{tabular}

The authors of the article believe that the land management concerning landscape planning, i.e. accurately defined prospective activities, focused on improvement, reclamation and creation of landscapes, is an important element in the system of integrated management of land use [11]. The main tasks of the landscape planning include nature protection and landscape management. One of the landscape planning peculiarities is that such planning maximally concerns landscape differentiation on the territory, its unique character and main functions. Such approach supports harmonization of "society-nature" relations, estimating the territory potential and determining priority directions of economic activity by arrangement of the landscapes territory with consideration of ecological restrictions $[12 ; 13]$. Stages of the landscape planning include:

- landscape assessment, including analysis of qualitative and quantitative characteristics of the territory;

- landscape forecast, including consequences of anthropogenic impact;

- planning of measures, including measures focused on protection and reclamation of nature.

The landscape planning is based on a detailed study of natural potential of the territory. Thus, such planning should be performed according to the principle "from a partial to a general one", starting from the local level of territory planning up to the international level [14].

Landscape planning on rural territories is considered as a multi-functional environment for living, combining of agricultural activities (crop cultivation, animal breeding) and non-agricultural activity (fishing, hunting, forestry, production of alternative sources of energy, recreation, tourism, folk crafts and others). Formation of esthetically attractive and arranged rural landscape is an important aspect.

Considering the existing system of territory planning in Ukraine and studying foreign experience of spatial planning on the principles of sustainable development, it is proposed to include the tasks of landscape planning in the process of planning of rural territories to solve ecological problems, first of all, in agricultural land use (Table 3).

The landscape program is a component of planning documentation and the base for ecologicallyfocused managerial and investment decisions concerning land use and protection at the regional level. Within a region, the landscape planning expects conceptual goals of protection, development and improvement of natural and cultural landscapes - formation of ecological network, extension of the lands of nature-reserve fund, etc. Such planning is based on functional zoning of territories, i.e. determination of boundaries of the territories (zones) of reasonable land use according to the types of land management with consideration of ecological-economic suitability of the land.

The frame landscape plan predicts solutions concerning natural ecosystem protection and cultural landscape formation, based on landscape analysis (inventory) of the territories and assessment of the results of human activity impact on nature. It solves the problems of reserving of territories for ecological intention and proposes ways of their solution. The frame landscape plan demonstrates numerous details of territory zoning. In Ukraine, such zoning can be made in the form of ecological, ecological-economic, anti-erosion and other kinds of land zoning. The frame landscape plan should go along with the solutions and measures, approved in the Scheme of territory planning in a region and the Scheme of land organisation concerning land use and protection.

The landscape plan is developed for the territory of a village council (a community) with numerous details of landscape characteristics of the territory - soil layer, relief, flora, fauna, etc. The landscape plan analyses and estimates negative phenomena and processes deteriorating ecological balance of the territory, proposes measures concerning improvement of ecological conditions of the territory, particularly land resources. Such measures include conservation of degraded and lowproductive agricultural land, reclamation of deteriorated land, land denaturalisation, contour 
organisation of agricultural land, forest- and phytomelioration. The landscape plan also solves the problem of territory reserving for ecologically-focused activity - tourism, recreation, organic arable farming and extension of environmental territories (structural elements of the ecological network). The landscape plan expects implementation of land organisation projects of land use and protection. Thus, the landscape plan is the base for solutions concerning arable land on erosion-dangerous slopes taking out of intensive use.

Table 3

Landscape planning within the territory planning system in Ukraine

\begin{tabular}{|c|c|}
\hline Document & Ecological tasks \\
\hline \multicolumn{2}{|r|}{ Regional level (a region) } \\
\hline $\begin{array}{l}\text { Scheme of territory } \\
\text { planning of a region }\end{array}$ & $\begin{array}{l}\text { proposals concerning environmental protection with consideration of the } \\
\text { National ecological network }\end{array}$ \\
\hline \multirow{3}{*}{$\begin{array}{l}\text { Regional program of } \\
\text { land use and } \\
\text { protection }\end{array}$} & optimization of agricultural land use \\
\hline & investigation and monitoring of land and soil \\
\hline & reduction of the area of deteriorated and degraded land \\
\hline Landscape program & $\begin{array}{l}\text { integral concept of priority directions of prospective nature management, } \\
\text { drafted on the principles of sustainable development }\end{array}$ \\
\hline \multicolumn{2}{|r|}{ Regional level (a district) } \\
\hline $\begin{array}{l}\text { Scheme of territory } \\
\text { planning in a district }\end{array}$ & proposals concerning protection of the territories and nature reserve stock \\
\hline \multirow{2}{*}{$\begin{array}{l}\text { Scheme of land } \\
\text { organisation } \\
\text { concerning land use } \\
\text { and protection }\end{array}$} & definition of the prospects of land use and protection \\
\hline & $\begin{array}{l}\text { proposals concerning organization of rational use and protection of the } \\
\text { land }\end{array}$ \\
\hline \multirow{2}{*}{$\begin{array}{l}\text { Frame landscape } \\
\text { plan }\end{array}$} & $\begin{array}{l}\text { argumentation of natural ecosystem protection and cultural landscape } \\
\text { formation }\end{array}$ \\
\hline & $\begin{array}{l}\text { proposals concerning eco-focused activities (agricultural, recreational, } \\
\text { touristic, and others) }\end{array}$ \\
\hline \multicolumn{2}{|r|}{ Local level (a village council) } \\
\hline \multirow[b]{2}{*}{ Landscape plan } & protection of biological diversity and natural ecosystems \\
\hline & $\begin{array}{l}\text { measures of land use ecologization (land conservation, land } \\
\text { renaturalization, land reclamation, soil revitalization, and others) }\end{array}$ \\
\hline
\end{tabular}

\section{Conclusions}

1. In the Ukrainian system of spatial planning, there is no accurately determined planning documentation concerning solution of ecological problems of land management and tasks of nature protection on the base of sustainable development. The authors of the article believe that such documents should be developed in the process of landscape planning as an important element of integrated management of land use.

2. In the authors' opinion the principal tasks of landscape planning are still not completely solved. The tasks include determination of the natural landscape framework of the territories; assessment of conflicts, occurring in the process of economic development of the territories; forecast of consequences of human activities for the ecosystem; formation of cultural landscapes; reserving of territories for ecologically-focused activities and extension of environmental territories.

3. In Ukraine, development of the aspects of landscape planning of rural territories needs coordination of the tasks of city-planning and land-surveying documentation at the regional and local levels. At the legislative level, it is important to include the frame landscape plan into the list of planning documents at the regional level and the landscape plan - at the local level.

4. In general, solution of ecological problems in land management of rural territories requires a complex approach with attraction of such processes as planning, motivation, organisation and control, which are focused on implementation of the principles of sustainable development. Esthetic education and ecological thinking of the society are very important aspects. The issues are 
going to be studied in the further researches concerning support of sustainable development of rural territories in Ukraine.

\section{References}

1. Dühr S., Colomb C., Nadin V. European Spatial Planning and Territorial Cooperation. 2010. London: Routledge. 32 Tab., 24 Abb., 10 Farbabb., 36 Box., 452 p.

2. Timothy B. Planning and Sustainability: The Elements of a New (Improved?) Paradigm // CPL bibliography, 1995/5, pp. 383-395.

3. Environmental Performance Index : 2016 [online][11.12.2017]. Available at: http://epi.yale.edu/data.

4. Державна служба статистики України: офіц. [online][11.12.2017]. Available at: http://www.ukrstat.gov.ua/. (In Ukrainian)

5. Розширений п’ятирічний звіт про опустелювання та деградацію земель. - К., 2012 - 45 с. (In Ukrainian)

6. Земельний кодекс України від 25.10.2001 № 2768-III [online][11.12.2017]. Available at: http://zakon3.rada.gov.ua/laws/show/2768-14. (In Ukrainian)

7. Склад та зміст містобудівної документації на державному та регіональному рівнях : ДБН Б.1.1-13:2012. - Київ. - 27 с. (In Ukrainian)

8. Про землеустрій: Закон України від 22.05.2003 № 858-IV [online][11.12.2017]. Available at: http://zakon5.rada.gov.ua/laws/show/858-15. (In Ukrainian)

9. Національна доповідь щодо завершення земельної реформи / за наук. ред. Л.Я. Новаковського. - К.: Аграр. наука, 2015. - 48 с. (In Ukrainian)

10. Курильців Р. Сутність та зміст інтегрованого управління землекористуванням // Землевпорядний вісник. - 2012. - № 4. - С. 32-35. (In Ukrainian)

11. Свропейська ландшафтна конвенція: Міжнародний документ від 20.10.2000 № ETS № 176 [online][11.12.2017]. Available at: http://zakon3.rada.gov.ua/laws/show/994_154/conv (In Ukrainian)

12. Антипов А.Н., Дроздов А.В., Кравченко В.В. и др. Ландшафтное планирование: принципы, методы, европейский и российский опыт / - Иркутск: Изд-во Института Географии СО PAH, 2002. - 141 c. (In Russian)

13. Opdam P., Foppen R., Vos C. Bridging the gap between ecology and spatial planning in landscape ecology. Landscape Ecology 16. 2002. pp. 767-779.

14. Landscape planning for sustainable municipal development. 2002. German Federal Agency for Nature Conservation (Bundesamt für Naturschutz, BfN). Leipzig. - 24 p. 